\title{
OPERATIONALIZATION OF THE STUDY OF THE “CHRONOTOPE OF COMMUNICATION ACTIVITIES OF CHILDREN WITH DEVELOPMENTAL DELAY" CONCEPT
}

\author{
Iryna Omelchenko \\ Institute of Special Pedagogy The National Academy of Pedagogical Sciences \\ of Ukraine
}

\begin{abstract}
Usage of a special psychology concept - chronotope of communicative activity of preschool children with delay of mental development is substantiated by the author in the paper. It is made clear, that chronotope of communicative activity is the complex socio-psychological phenomenon which is constructed by personality as a result of his / her real and virtual co-operation and communication in measuring of everyday and unordinary reality with Other, that is opened out in timeline and value-semantic continuum of life. The constituents of space of communicative activity at everyday level of consciousness that are incarnated in research of direct co-operation and communication with adults and same-year fellows are marked. The constituents of space of communicative activity have been exposed at extraordinary level of consciousness which is realized in the mediated co-operating and communication with a favourite toy and imaginary partner, with animation personages. It was emphasised that the conceptual framework of the developed concept is integrity based at different approaches, at systematic, axiology, cultural, historical; social and psychological; subject-environmental and body-based, technique scientific approaches that are synthesized in the personality-oriented paradigm of education.

KEY WORDS: chronotope, communicative activity, preschool children, delay of mental development, consciousness, ordinary and extraordinary reality of consciousness.
\end{abstract}

\begin{abstract}
Anotacija
Straipsnyje pagrindžiamas specialiosios pedagogikos sąvokos sutrikusios raidos ikimokyklinio amžiaus vaiku komunikaciness veiklos chronotopas vartojimas. Komunikacinès veiklos chronotopas yra sudètingas socialinis-psichologinis reiškinys, konstruojamas asmenybès, jai realiai ar virtualiai sąveikaujant ar bendraujant su Kitu kasdienejje realybejje. Šis chronotopas skleidžiasi laiko ir vertybių semantiniame gyvenimo kontinuume. Skiriami komunikacinès veiklos erdvės kasdienėje sąmonèje dèmenys, analizuojami tiesioginès sąveikos ir bendravimo su suaugusiaisiais bei bendraamžiais tyrimuose. Šie komunikacinès veiklos demenys puikiai atsiskleidžia sąveikaujant ir komunikuojant su mėgstamu žaislu, įsivaizduojamu partneriu ar animaciniais personažais. Pabrèžiama, kad komunikacinès veiklos chronotopo konceptualiame kontekste integruojami ịvairūs požiūriai: sisteminis, aksiologinis, kultūrinis, istorinis, socialinis-psichologinis, subjekto ir aplinkos, pagrịstas kūnu, taip pat moksliniai požiūriai, apimantys į asmenybę nukreipto ugdymo paradigmą.

PAGRINDINIAI ŽODŽIAI: chronotopas, komunikacinè veikla, ikimokyklinio amžiaus vaikai, sutrikusi protinè raida, sąmoné, įprasta ir ypatinga sąmonès realybė.
\end{abstract}

DOI: http://dx.doi.org/10.15181/tbb.v72i3.1169 


\section{Introduction}

At the present stage of psychological science, modelling and studying of system objects, searching of heuristic mechanisms by which a researcher can reveal new horizons of knowledge about psychological phenomena is very important in the post-non-classical dimension of scientific rationality. Hence, the issue becomes important to search the means for the constructive organization of communication of preschool children with developmental delay with Others in the space of society, culture and personalized "I" with cause understanding and Other behaviour prediction and with using of a powerful regulator - a value-sense field of the Universe.

In the context of our study, the "chronotope of communicative activities of preschool children with developmental delay" concept is the basis for meaningful communicative activities with another person or object (adults, peers, a favourite toy, an imaginary companion, animated characters). Therefore, this approach gives special relevance to operationalization of the "chronotope of communicative activities of preschool children with developmental delay" concept in the special psychology discourse. That is why, the purpose of this article is to present conceptual substantiation and to determine links between the study of theoretical apparatus and its methodological tools by creating a system of empirical indicators characterizing the studied object.

\section{Methods}

Theoretical methods: a deductive method (axiomatic-deductive and hypothetical) was used for systematic description of the phenomenon under study; modelling (structural and functional) was used for construction of the model of a social and psychological phenomenon - the chronotope of communicative activities of preschool children with developmental delay.

\section{Results and discussion}

Spatial-temporal determinant formation for communicative activities is realized during communication, interaction and dialogue of preschool children with developmental delay with adults, peers, an imaginary companion, a favourite toy, animated characters in an ordinary and extraordinary reality of consciousness.

The works of E. Subbotskiy (1984, 1988, 1990, 1999, 2007) set forth most completely and consistently based on extensive experimental database the ideas as for consciousness fundamental structures and it dynamics in ontogenesis within 
the Western European psychological tradition that follows Piaget; he considers sense structures as products of child's real life relationships with his/her activities that, unlike knowledge, are not controlled and can remain unconscious.

The works of E. Subbotskiy $(1999,2001,2007)$ develop the idea of individual consciousness as a system of two distinct realities: an "ordinary reality" of consciousness, which includes "rational structures" (properties of physical objects), as well as "fundamental obscurity of perception" and an "extraordinary reality of consciousness" (the world of fantasy, dreams, art, children's games, fairy tales). The most important thing in the extraordinary reality is acknowledgment that human fantasy is "materialization of the world of possibilities".

So, communicative activities in games are the only way to master the extraordinary reality, therefore, they occupy such an important place in lives of preschooler with typical and delayed mental development. Being agreed with E. Subbotskiy, we offer a new perspective on communicative activities in games as a psychotherapeutic tool by which it becomes possible to form communication and interaction with Other in culture (with adults, peers and animated characters); with personalized another (a favourite toy and an imaginary companion).

The analysis the "chronotope of communicative activities of preschool children with developmental delay" concept should be done for determination of its subject content. We agree with E. Nekrasova who determines the chronotope as a person's dynamic value-sense space having its past, present, future; it is flexible, rises from the activity of an individual interacting with environment, and his / her activity is distributed in space and time. The "chonotope" concept, including person's subjective time and space of life that are inextricably linked, is required for understanding of the mechanisms of person's multidimensional world generation in the unity of hierarchical, subjective and objective coordinates that appear and act in real life and that the chonotope determines providing steady and aimed system functioning (Nekrasova, 2003, p. 204).

The "chronotope of communicative activities of preschool children with developmental delay" concept is understood by us as inter-subject and intra-subject communication, interaction and dialogue (external and internal) implemented by a child in time and space and a value-semantic life dimension and is a multidimensional system of relationships with Other: in a society (with real adults and peers); culture (through adults and peers characters from animated films); a personalized Other (a favourite toy and an imaginary companion). Preschooler's communication, interaction and dialogue are implemented in different spaces (with adults, peers, and with a favourite toy and an imaginary companion, animated characters) (see. Fig. 1). 
Thus, during communication activities, a personality, on the one hand, is formed and manifested, and the other hand, determines flow of various forms of subjective reflection and uses its products. The chronotope of communicative activities of preschool children with developmental delay is implemented at different levels of consciousness functioning: ordinary (communication, interaction and dialogue with adults and peers) and extraordinary (communication, interaction and dialogue with a favourite toy, an imaginary companion and animated characters) that acquire system properties; these levels interpenetrate, enrich each other, define new contexts and, thus, change actual preschooler's communication and interaction with Other: the experience of real interaction affects art image perception, and vice versa, a real Other obtains attributes with features of a symbolic and personalized Other.

Temporal (time) coordinates in the chronotope of communicative activities are implemented through perception of own communication "here and now" and through cause understanding and behaviour forecast as for Other by a child with developmental delay; and values and senses are the first dimension of human life (Zinchenko, 2011), and then, they are defined by us within a value-semantic component of the chronotope of communicative activities (Omelchenko, 2013, 2014).

The value-sense component of the chronotope of communicative activities is its system-creating component (Zinchenko, 2011). The chronotope of communicative activities is implemented in the following communication sectors: interactions and dialogues of preschool child with developmental delay.

The first sector is represented by communication and interaction with adults, those whom a child relates to adults (family members, neighbours, teachers, strangers, etc.).

Communication with adults is formed mainly on the base of cognitive interaction motives at a middle preschool age and personal motives for interaction in an elder preschool age. An elder preschooler seeks adult's recognition and support; he/she has a desire of productive and lasting communication, can be emotionally involved in interaction with adults; capable to out-of-context contacts that are activated by cognitive motives at a middle preschool age, and personal motives in an elder preschool age.

There are significant Other adults (a mother, a father, grandparents, educators) in the space of preschooler's communicative activities. Therefore, child's attitude to significant Other adults is one of the defining characteristics of the chronotope of communicative activities. 


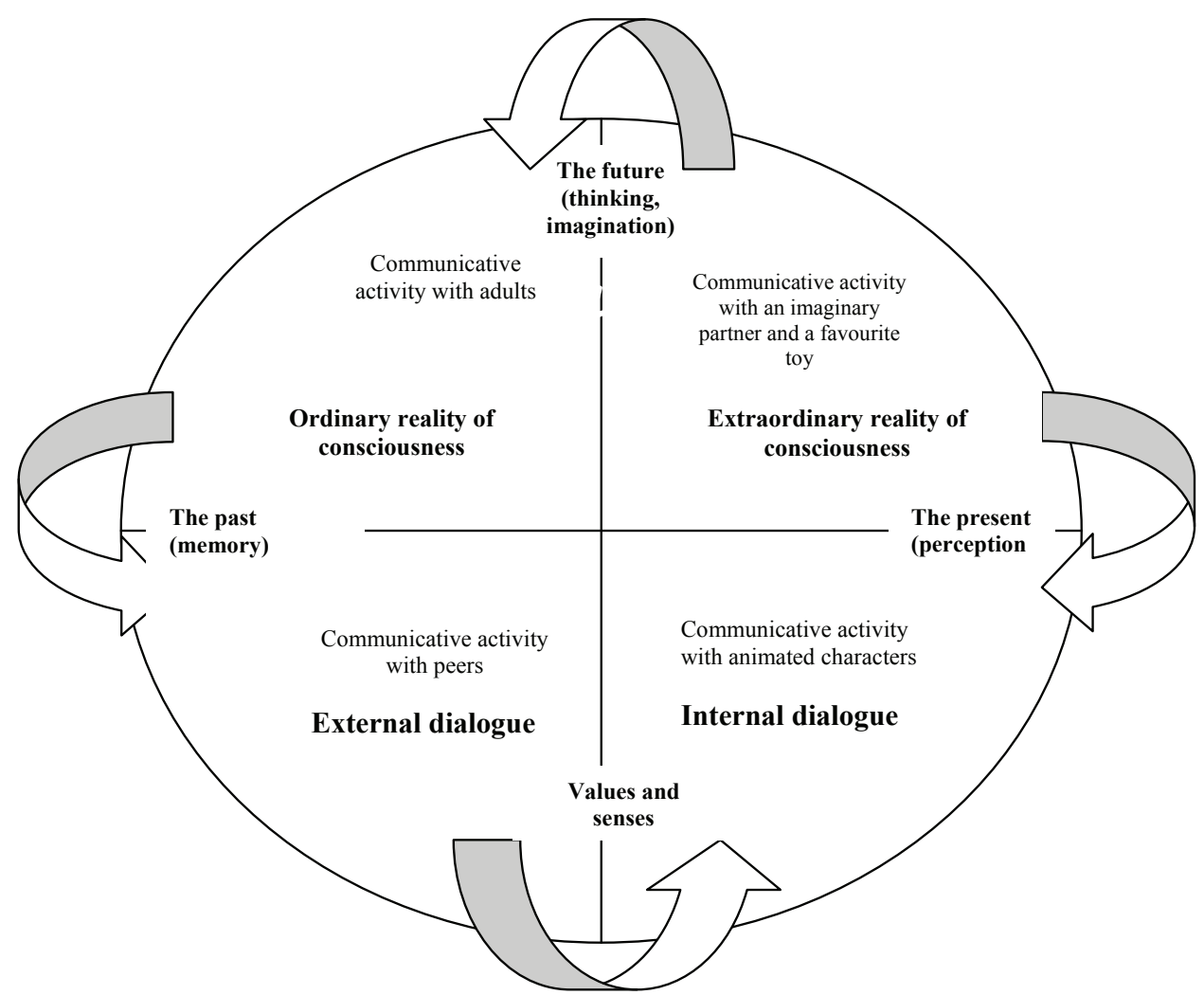

Fig. 1. Chronotope of communicative activities of preschool children with developmental delay

The attitude is formed as personal experiences, feelings that are emotionally significant for an individual. The attitude to Other is a generic concept, it is more generalized and includes numerous of specific concepts, among which mindsets have an important place as some form of selective attitude that organizes selection, perception and interpretation of information. Thus, attitude can be positive, even, contradictory, aloof-distancing.

We consider child's communication with peers who are equal subjects of the space-time continuum of child's communication with the social environment as the second sector of communication, interaction and dialogue of children with developmental delay (V. Abramenkova, M. Kosven, M. Osorina, A. Ruzska, etc.).

The important indicators of the chronotope of communication activities with peers are: a content and nature of partners-peers' interaction (attention focusing on a peer, desire to communicate with him / her, ability to act in the same semantic 
field); language support of partners' activities (prevailing communication means: visual, subject-active, expressive facial, language); a stage of preparation for joint activities (joint activity planning, task performance time); conflict situations (ways of conflict resolution: productive or unproductive); dialogue quality (a ratio of initiative expression and expressions-responses, addressing of questions, messages and encouragements, presence of question repetitions, participants' positions in a communicative situation).

Regulation of the communication chronotope is mediated with cultural forms; one of the cultural canons is sovereignty / deprivation of psychological space boundaries where communication is realized. The basic concept of the subjectenvironmental approach is the concept of a psychological space and personality's psychological sovereignty. C. Nartova-Bochaver indicates that the psychological space, its measurement, boundaries and their stability can be understood as components of personality's structure and as characteristics of the fundamental aspects of his / her functioning in the society, and as elements of persons' self-identity (Nartova-Bochaver, 2008). The space with integral boundaries gives a person ability to maintain his / her personal autonomy and defined as a sovereign space, and the space with ruined boundaries is understood as a deprived one, in this case a need for privacy, an ability to manage communication, interaction and dialogue with the world are deprived.

That is why, it is important at preschool childhood, firstly, to study sovereignty / deprivation of psychological space boundaries at inter-subject communication, interaction and dialogue with peers, which is possible to perform under the subject-environmental approach during diagnosing of a non-differentiated real and role position in a game and fine arts activities; over-travel outside a plot; a space that the child separates during the game (an opened / closed gaming space: the ability to let other children into his / her territory, to ban other children from his / her game or fine arts space); boundaries of the gaming space established with toys and other items, attention is paid whether the child is secluded by highlighting his/ her separate space; the size of his / her space for communication, interaction and dialogue and its border integrity; which objects the child chooses to protect his / her chronotope of communication activities and how he / she interacts with other children.

Second, it is important to study sovereignty / deprivation of psychological space boundaries at intra-subject communication, interaction and dialogue with others, it is possible to perform under the body-oriented approach and it can be described by the following indicators: boundary formation and stability; the quality of a contact with Other - boundary permeability, integrity; a strategy for the construction of a contact with Other - aggressive behaviour / contact avoidance. 
A system-building mechanism for the study of the chronotope of communicative activities with peers of preschool children with developmental delay is a "substantive dialogue", "cooperation", "co-working". As for the "joint activity" category, it is applied mainly to school children, as the main difference, according to the views of A. Petrovsky and M. Yaroshevskiy, is "the presence of a common goal that means a foreseen result of joint activities that corresponds to common interest and support needs of each participant included in the joint activities. At preschool age, children are just beginning to know themselves and others in organized by adult cooperation, they often are captured by fun game motives and do not always realize end results as consequences of their joint work" (Petrovsky, Yaroshevskiy, 1990, p. 51).

Therefore, as for preschool children with developmental delay, it is appropriate to talk about their interaction as a process of direct or indirect influence of objects (subjects) on each other that gives rise to their mutual conditionality and links. An interactive situation unites preschool children in the group, brings them together and establishes an identity between them.

The third sector is nearly unexplored, it is intra-subject communication, interaction and dialogue with a favourite toy and an imaginary companion (a quasiobject), almost any child plays with it different variants of communicative activities, establishes friendly relationship, appeals in different situations of his / her life (V. Abramenkova, O. Vasina, M. Kagan, S. Minyurova, V. Mukhin and others).

Communication, interaction and dialogue with a favourite toy. During development of a self-image, a child "humanizes" objects of his / her environment. In addition, during child's communication and interaction with objects of his / her environment, the child "takes-out", during such "humanization", to these objects his / her own psyche, feelings, and inner world. In fact, we can see in child's representation of the inner world of child's favourite toy a picture of his / her own life and experience. It is an example of an exteriorized identification (V. Mukhina) when child's own feelings, motives are transferred to others. A child not only believes that his / her favourite toy has certain features and experiencing certain feelings, but he / she is sure that he/she constructs a communicative partner's image projecting his / her own thoughts and feelings, desires to "the model". A preschooler can be easily identified with a doll or other favourite toy: he / she attributes a particular state to the doll that is known to the child (an exteriorized identification), then the child defines his / herself as the doll state and acts in a game on its behalf of the do; and on own behalf. Not only the game plot, but experience of child's identification captures the child and gives the game a special significance.

The favourite toys phenomenon in a child's life has practically not been studied in the psychological theory, there is no scientific description and definition, 
there are only a few references to it in the works of A. Vasina, A. Leontiev, S. Minyurova, V. Mukhina, A. Spivakovska.

In addition, a favourite toy has not been studied as a subject that support development of child's intra-subject communication, interaction and dialogue, therefore its role in communicative activity development has not been examined, there are just some data that indicate indirectly but do not prove that a favourite toy can act as a humanized communicative subject. C. Minyurova determined prevalence of the toy indicator for five-six year old children; the author relates this fact to a growing child need to demonstrate him / herself through activities. The child's need in interaction with people is not satisfied, and he / she addresses for communication and friendship to toys, attributing human qualities to them. Attributing these qualities to toys, the child "humanizes" them. The process of environmental object "humanization", according to S. Minyurova, is a very important indicator of child psyche functioning (Minyurova, 1995).

Thus, the process of outside world humanizing and the gradual outward shift of child's skills, experiences, opinions through interaction with external objects and products of this interaction is the basis for child's mental development. The next indicators can be studied as for the favourite toy phenomenon of preschoolers with typical as well as delayed mental development: longitude of its existence; features of child's attitude to a favourite toy; child's communication and interaction with his/her toy; child's communication and interaction with his / her toy from an adults' perspective.

Communication, interaction and dialogue with an imagery companion. The problem of an imaginary companion is being conceptualized over a century in children's literature (J. Barry, S. Lagerlof, A. Milne, A. Lindgren and others), but this phenomenon remains unclear because of its extreme functional mobility. The modern psychology emphasizes multiple functions of an imaginary companion: an interlocutor, a helper, a protector and a game partner (A. Behoyan, A. Illarionova, M. Kagan, I. Omelchenko, O. Chesnokova, M. Yaremchuk). Some researchers (M. Taylor, B. Cartwright, S. Carlson 1993) are inclined to regard this phenomenon as an abnormal mental development manifestation. For others (J. Piaget, A. Dyachenko, R. Granovska, I. Nikolska), it is an exotic form of normal age formation existence.

Psychologists during individual psychological diagnostics should pay attention at the presence of the imaginary companion phenomenon at preschool children with developmental delay, because its presence indicates the predominance of child's communicative forms involving a quasi-partner - dialogue with the other "I". 
Being agreed with T. Kerimov, V. Petrovsky, we believe that this ability is the basis of personalization and is provided by subject' individuality resplendence and diversity of means by which he / she can exercise a personalizing impact in communicative activities. It was determined that subject's personalization is fulfilled in the case of its importance for another, its reference and emotional appeal. A researcher T. Kerimov believes that an Other is "beyond any disclosure, understanding, explanation and visibility" (Kerimov, 2007, p. 11). Since we can neither cognize an Other in full difference from "I" nor cognize ourselves in the Other, so "I" cannot go out own boundaries to fully merge with the Other. It means that the source of any "sense of self in an Other" is a person him / herself. An Other exists only through the prism of "I", and hence the ideal representation of "I" in the Other exists only because of "I". Since a person him/herself is an author of "I" estimation from the point of view of a "significant Other" (basing or vice versa ignoring real feedback), the "I" estimation made by a person as other "I" can be also significant and developing.

The imaginary companion phenomenon of preschool children with developmental delay can be studied by using diagnostic indicators. A practical psychologist can determine a number and duration of existence of his / her imaginary companion; child's age at the time of imaginary companion appearance and disappearance; child's attitude to it; ways, forms and frequency of child's interaction with his / her imaginary companion; features and properties of his / her imaginary companion; parents' attitude to his / her imaginary friend.

The fourth sector of the chronotope of communicative activities is presented by the space of communication, interaction and dialogue with animated characters (M. Kagan, N. Nosov, A. Orlov, P. Rainer and others).

E. Popov defines animated films "as an art type that belongs to audiovisual arts and which distinctive feature is humanizing", "psyche" attributing to images that are created artificially with different expressive techniques and means. It is necessary to clarify that animation, being a part of audiovisual art, can exist without audio support, but sound helps create a more holistic and bright artistic image (Popov, 2011).

In the context of the chronotope of communicative activities of preschool children with developmental delay, it is important to examine interaction with animated characters through the prism of para-social communication.

Para-social communication means in psychology of mass-media an imaginary direct (face-to-face) interaction that occurs between a media-character and its audience. The behaviour of these characters during each interactive event (in our case it is demonstration of an animated series) helps a viewer to form his/her 
opinion about this character, which is then transferred to the next episode of parasocial interaction.

O. Voznesenska has discovered the mechanism of substitution of child's real interpersonal relations with para-social ones that are characterized by a gap between emotional state and participation in events, so a trend begins to dominate in a child's life world of destruction in the chronotope of a space "here and now" unity: experiencing emotions at the tail of on-screen reality, engaging into it without real participation, building of relationships with a media-character in a "there" virtual world, a child lives intensely "not here". Moreover, in this case while the real surrounding world becomes "virtual" because an easy "not here" life begins to be transferred on the real world, this easy virtual world does not require personal involvement, actions, efforts to resist reality, responsibility for its ordering and own contribution into it (Voznesenska, 2010).

So, simple viewing of animation products can provoke emergence of para-social relations with a media-character and promote formation of the chronotope of communicative activities with real adults and peers with the "not here" principle. Therefore, it is important to develop such technology of interaction with animated characters that would provide preschooler's personal involvement, initiation of communicative action, efforts of real communication with adults and peers. This task necessitates joint work of experts, including close collaboration of psychologists, teachers and parents to prevent negative influence of the screen art and to substantiate and develop a technology for formation of the chronotope of communicative activities with animated characters.

Communication, interaction and dialogue with animated characters of preschool children with developmental delay can be studied with diagnostic indicators. A practical psychologist can diagnose how a child accepts an offer to play an animated film, whether he / she is sensitive to changes in the plot made by an adult as a game partner; whether the child needs adult's help (introduction of toys or adult's show how to play); a game form constructed with the animated film plot (two-stroke, single-stroke games, games with fuzzy structure).

The fifth sector of the chronotope of communicative activities is presented by the time of communication, interaction and dialogue of a preschooler with Other. Internal and external dialogue is implemented not as a still closed whole, but as a chain of events. In addition, time for a person is not just a length, a flow, a sequence of changes. We can not only distinguish time units by counting minutes or hours, we view time as a unity of three states - the past, the present and the future.

The "present" concept has theoretical difficulties, because it can be represented as a moment, as temporariness; if this moment could be, at the first, fixed, and then be separated in its pure form and without adding of the past of the future. The 
concepts of the past and the future in the context of life experience are revealed through a very specific content: the past is a history or personal biography and the future is an aim, intention, a plan consisting of a more or less detailed picture of the future.

Understanding of the time chronotope of communicative activities with Other of preschool children with typical and delayed development involves understanding of the causes of other person's behaviour in the past and forecast for future his / her actions and perception of him / herself and the other persons "here and now". A practical psychologist can diagnose these temporal (time) indicators using methods that have been developed under the modern approach "Mental model" or "Theory of mind" (Wellman, 1990; Flavell, 2000; Sergienko, 2002) that examines the genesis of understanding of a Other' and his / her own psyche, a system of cognitive representations of mental phenomena. The mental model means a system of generalized knowledge about own psyche and psyche of other people.

The sixth sector of the chronotope of communicative activities is its value-sense dimension. Time is the fourth dimension of the space, but, in the context of communicative activities in preschool children with developmental delay, it is the fifth component of the chronotope of communicative activities, and values and senses is the sixth component. It should be emphasized that, according to V. Zinchenko, values and senses is the first dimension of human life. Works of A. Leontiev, B. Mukhina, S. Rubinstein, T. Pirozhenko, E. Subbotskiy, S. Jacobson and other researchers have shown the importance of "values", "personal vision of reality", "value orientations" for personality communicative development.

Person's value-sense development is prolonged throughout person's all life. During preschool ages, value-sense relations act the basis of value-sense development; they are manifested in attitude to culture values, family and strangers, in verbal and nonverbal ways of communication, in interaction, cooperation and communication. Values and senses acquired by a child become the reference in the system of relations, and he / she reveals senses in various life situations (playing, communication with peers, adults, a favourite toy, an imaginary companion and animated characters, etc.).

The values of life and culture are directed to the main points of the real world of an act: I-for-myself, Other-for me and I-for-Other. All spatial-temporal and content-sense values and relationships are directed to these communicative-dialogical relationships: I, Other and I-for-Other (Bakhtin, 2003, p. 49-50). A person's value-sense structure is the result of a reflection in an individual consciousness of the values that exist in the culture. The structure of individual values of the representatives of particular cultural environment is different from the value structure of individuals for whom this culture is a new environment. 
The value-sense component of the chronotope of communicative activities of preschool children with developmental delay can be studied via diagnostic indicators. A practical psychologist can diagnose how a child is able to symbolize as the basis for the meaning generation, to perform an internal dialogue and decentration as meaning generating mechanisms, the psychologist can find out presence of personal meaning and formation of a need for benefits to Other and their extent in time, sociogenetic value of communicating with Other.

\section{Conclusions}

1. The chronotope of communicative activity of preschoolers with normal and delayed development is a highly complex object diagnostics and envisages psychologist's orientation in value and social-cultural contexts from the perspective of "person-world" relationship understanding. Given a complex and many-element structure of the chronotope of communicative activity, the most appropriate methodological guideline for this case is the post-non-classical type of scientific rationality, defined by us based on the multi-paradigm and inter-paradigm methodology and on main ideas of the person-cantered educational paradigm characterized by an integrity that is formed by integrating of system, axiological, cultural-historical, social-psychological, subject-environmental, body-oriented scientific approaches and is represented as a set of theoretical propositions to study the operatsionalized concept.

2. The structure of the chronotope of communicative activities of preschoolers with developmental delay that we conceptually substantiated and operatsionalized can be used in the diagnostic performed by practical psychologists.

3. We recon determination of communicative activity formation at different levels of consciousness functioning - an ordinary (communication and interaction with adults and peers) one and an extraordinary (communication and interaction with a favourite toy and an imaginary companion, animated characters) one, time and value-semantic levels - as parameters and indicators of mental development of preschool children with developmental delay that practical psychologists can use to study the chonotope of communicative activities of this category of children.

Gauta 20150916

Pasirašyta spaudai 20151005 


\section{References}

Bahtin, M. M. (1996-2003). Sobranie sochinenij. Moskva: Jazyki slavjanskoj kultury.

Voznesenska, O. L. (2010). Vikovi osoblyvosti vzayemodiyi dytyny z media v rodynnomu konteksti. Materialy II Vseukrayinskoho psykholohichnoho konhresu, prysvyachenoho 110 richnytsi z dnya narodzhennya H. S. Kostyuka, T. 2. Kyyiv: DP «Informatsiyno-analitychne ahentstvo», p. 30-35.

Zinchenko, V. P. (2011). Cennosti v strukture soznanija. Voprosy filosofii 8: 85-98.

Kerimov, T. H. (2007). Gumanitarizacija obshhestvoznanija i problema drugogo. Drugoj v prostranstve kommunikacii. Sbornik nauchnyh statej. Kazan: Kazanskij Gosudarstvennyj universitet, p. 7-21.

Minjurova, S. A. (1995). Psihologicheskie osobennosti nagljadnoj formy samosoznanija v detskom vozraste. Ph.D. Psihologicheskij institut rossijskoj akademii obrazovanija.

Nartova-Bochaver, S. K. (2008). Chelovek suverennyj: psihologicheskoe issledovanie subekta v ego bytii. Sankt-Peterburg: Piter.

Nekrasova, E. V. (2003). Hronotop i hronotopicheskie harakteristiki cheloveka kak psihologicheskoj sistemy. Polzunovskij vestnik 3-4: 203-210.

Omelchenko, I. M. (2013). Psihologichni osnovi doslidzhennja prostorovo-chasovih determinant komunikativnoï dijalnosti u ditej iz zatrimkoju psihichnogo rozvitku. Problemi suchasnoï psihologiï 19: 492-502. Kamjanec-Podilskij: Aksioma.

Popov, E. A. (2011) Animacionnoe proizvedenie: tipologija i jevoljucija obraznyh sredstv. Ph.D. Sankt-Peterburgskij gumanitarnyj universitet profsojuzov.

Psihologicheskij slovar. (1990). Moskva: Politizdat.

Subbotskij, E. V. (2002) Razvitie individualnogo soznanija kak predmet issledovanija jeksperimentalnoj psihologii. Psihologicheskij zhurnal 23 (4): 90-102.

Omelchenko, I. (2014). Tools for psychological diagnostics of chronotope of communicative activity of preschool children with delay of mental development: theory and technique. TEKA-Archives of the Commission of Medical Sciences 2 (1): 27-33. Polish Academy of Sciences Branch in Lublin. Lublin: Towarzystwo Wydawnictw Naukowych LIBROPOLIS. 
